\title{
Working for Free \\ Illegal employment practices, 'off the books' work and the continuum of legality within the service economy
}

\begin{abstract}
Much of the literature on illegal labour focuses on the exploitation of illegal migrants and, by extension, the trafficking and smuggling networks that transport them to destination countries. Using evidence from two projects that investigated working conditions in the formal service economy, the paper presents evidence of 'off the books' work, illegal employment practices such as denial of benefits and the minimum wage, as well as work trials where labour is exploited for free. By considering political economic imperatives, this paper argues that employees in both the formal and informal economy are dispossessed of rights, pay, benefits and security in order for employers to profit by surplus value and the circulation of capital. The real 'organised crime' of illegal labour is neoliberal political economy and its decimation of employment protection.
\end{abstract}

KEY WORDS - illegal labour, political economy, social harm, illegal employment practices, exploitation, neoliberalism

Illegal labour garners attention in conjunction with legitimate concerns over human trafficking, migrant smuggling and modern slavery (UNODC 2016). As such, smuggling networks and organised crime groups are the purview of criminological research (Papanicolaou 2008; Bales 2012; Campana and Varese 2015). The original contribution of this paper is to explore illegal labour and employment practices in the context of the formal economy. Through data drawn from two ethnographic projects, this paper contends that the focus on shadow or informal economies (Webb et al 2009) misses a broader point about neoliberal political economy. Under conditions of neoliberal retrenchment across Europe and the US, all labour markets are squeezed, conditions of employment deteriorate and the coercive laws of competition (Marx 1990 [1867]) at the heart of a capitalist economy encourage employers and businesses to seek advantages that in some cases result in illegal employment practices. While undoubted differences exist between the working experiences of illegal migrants and formal service economy employees (Ahmad 2008a), and no moral 
equivalence is drawn here between the obvious distinction between migrant workers smuggled/trafficked across borders to work in informal economies and those engaged in formal, legitimate yet albeit exploitative forms of labour, the aim of this paper is to identify the parallels and similarities that emanate from the demands of neoliberal capitalism.

First, the paper will outline the key literature on illegal labour. This will demonstrate the focus on illegal migrant labour (Boswell and Straubhaar 2004), organised crime, smuggling, trafficking and slavery (Nikolic-Ristanovic 2004) but go on to widen the analytical lens to consider contemporary employment practices within the formal economy (Lloyd 2013). In doing so, the paper will position the illegal/legal dichotomy as part of a political-economic continuum (see also Hall and Antonopoulos 2016; Large 2018; Hillyard and Tombs 2017). Second, the paper will set out the methodological underpinning for the empirical work upon which this argument is based. Two ethnographic studies of the formal service economy of a region in North-East England provide a range of observational and interview data that the subsequent discussion will draw upon.

Third, the paper will present this data and outline a number of legal and illegal employment practices within the service economy that serve to steal from employees and deny precarious workers entitlements, rights and money. Finally, the paper will engage in a theoretical discussion that analyses empirical evidence from a political-economic and social harm perspective. Using Harvey's (2010) concept of 'accumulation by dispossession', the illegal employment practices exhibited within the formal economy represent the normal functioning of a capitalist system. From a social harm perspective (Hillyard and Tombs 2004; Pemberton 2016; Lloyd 2018), the continuum of legal and illegal practice evident across both the formal and informal labour markets reflect the imperatives of capitalism in its current neoliberal phase; to squeeze labour costs and extract profit wherever and however possible (Scott 2017). At one extreme, this facilitates the use of modern slavery by unscrupulous groups and individuals while further along the continuum formal employers may deny contractually agreed entitlements in order to extract free labour from employees. Ultimately, the paper argues that the more significant 'organised crime' associated with illegal labour is the organised decimation of workplace protections orchestrated by neoliberal capitalism. 


\section{Contextualising 'illegal labour'}

Discussion of illegal labour presents a number of factors; the illegal status of employees (Boswell and Straubhaar 2004); illegal or informal employers (Ahmad 2008a); and illegal employment practices within formal and informal economies (Scott 2017). This paper focuses primarily on the latter but this section will discuss all three to indicate a continuum of practice.

Boswell and Straubhaar (2004: 4) define illegal labour as 'a product of two factors: legislation which restricts possibilities for legal labour migration; and the incentives of employers to circumvent the costs of employing legal labour'. Illegal labour is, in this definition, bound up with legal and illegal migration and the role of migrant workers but it also strikes at the heart of the argument central to this paper; the incentives available to employers willing to flout legislation and profit from the employment of illegal labour. The connection between illegal labour and migration is a starting point for a consideration of the literature but the empirical evidence presented below may require a wider definition of illegal labour.

The focus on illegal labour often codifies forced labour and exploitation as a corollary of organised criminal practice; gangs of organised criminals trafficking human cargo for the purposes of 'modern slavery', sexual exploitation or migrant labour (Antonopoulos and Papanicolaou 2018; UNODC 2016; Shen et al 2013; Boswell and Straubhaar 2004). As the economic liberalisation of the neoliberal epoch opened up national borders for transnational and global trade and the free movement of people for work, opportunities emerged for the smuggling/trafficking of illegal migrants across national borders for work purposes or prostitution (Antonopoulos and Winterdyk 2006; Papanicolaou 2008; Nikolic-Ristanovic 2004). As noted by Webb et al (2009), the informal and illicit economy costs the formal economy both money and jobs although it does create value for the employer or business willing to circumvent the legal restrictions on certain activity.

The debate around illegal labour often focuses upon migrant labour and illegal entry (Entorf and Moebert 2004), the conditions of employment within the informal economy (Ahmad 2008a, 2008b) and the spectre of competition between indigenous workers and newly arrived illegal immigrants (Venturini 2004; see also Winlow et al 2017). However, legal migration for work purposes has also been identified as a form of 'unfree' labour (Gordon 2018); workers 
brought to a country by an employer can find their ability to move between occupations restricted by the conditions of their migration. While neoliberal ideology evokes freedom and flexibility for workers, the reality for many is one of restriction and limitation, regardless of legal status. Further forms of 'unfree labour' include the coercion of prisoners to work and the sanctions attached to 'workfare' regimes in what Wacquant (2009) calls 'liberalpaternalist' welfare states (see Hatton 2018). The use of coercion in relation to labour abounds both in terms of legal processes associated with welfare, penal and immigration policy as well as the coercion of organised crime groups and traffickers (Campana and Varese 2015).

Smuggled and illegal migrants arrive in destination countries and often find limited opportunities within formal labour markets and much of the literature points to exploitation within the informal service economies populated by illegal migrant workers (Ahmad 2008a, 2008b; Boswell and Straubhaar 2004; Ram et al 2002). Ram et al (2002) investigated illegal migrants in UK restaurant work and the clothing trade and identified similarities and differences in practice. Restaurants faced recruitment problems but did not set out to hire illegal workers; it was often an unintended consequence. In the clothing trade, employers recruited illegal workers because they were inexpensive and reflected a need to cut costs. Employers in the clothing trade also paid below the minimum wage and while the restaurant trade displayed parity between legal and illegal workers, illegal workers often worked at least fifty hours a week which brought their pay down below the minimum wage (Ram et al 2002).

In Ahmad's (2008a, 2008b) study of illegal Pakistani migrants working in London's 'ethnic enclave service sector', there was a clear combination of pressures unique to illegal migrants and conditions ubiquitous across the service economy more generally. All workers within what Ahmad (2008a) refers to as 'ethnic economies' faced long hours, poor conditions, low pay and insecurity, much the same as formal service economy workers (Lloyd 2018) but also faced the additional burdens associated with the cost of migration and the inability to achieve 'structural embeddedness' or upward social mobility. Ahmad notes that mainstream industries are increasingly demanding and problematic workplaces due to wider neoliberal restructure and the competition fostered within sectors and markets (see Streeck 2016) but the informal economy is largely unregulated and therefore more demanding and acute. This 
contrast between the legitimate economy and the rights and protections afforded by legislation with the informal and illicit economy clearly shows disparities between illegal migrant workers and legal formal work but, as the evidence below will suggest, is part of a continuum of neoliberal violence against workers that drives and facilitates a range of legal and illegal action.

Moving beyond migrants and illegal work, Williams and Horodnic (2017) explore illegal employment practices carried out within the formal economy. Using the results from a Eurobarometer survey across European workplaces, they identified one in every 33 workers in receipt of an under-reported salary, mostly vulnerable individuals or those employed in small businesses. Employers offer an official 'declared' salary in writing but also a verbal 'envelope wage' that is hidden from the authorities and allows the employer to avoid full social insurance and tax liabilities. The employee will inevitably work longer hours and forego full annual leave entitlement compared to the contracted agreement. This study argues that practices such as this are concentrated largely in European countries with lower levels of economic development and less modernised state bureaucracies. However, it brings us into the formal economy and demonstrates that illegal labour practices exist outside of migrant workers and the unregulated or informal economy.

Behling and Harvey (2015) contend that the UK construction industry responds to legal, fiscal and economic processes with 'false self-employment'; construction workers registered as self-employed for tax and benefits purposes but ostensibly bound to an individual contract or employer. Large scale tax evasion and the erosion of employment rights is the inevitable result of a 'degenerative competition' whereby all employers and contractors risk losing out on work unless they 'play the game' and cut labour costs. Furthermore, Webb et al (2009) note that entrepreneurs with a particular 'social identity' will exploit illegal opportunities in the informal economy but often transition into formal economic practices, as well as straddling the boundary between legal and illegal practice, wherever it suits their interests. This demonstrates not only the value of a social harm perspective that can account for legal as well as illegal activity (Hillyard and Tombs 2004) but also the motivation behind illegal employment practices. 
Scott's (2017) work on labour exploitation and work-based harm is important as it recognises a continuum of problematic employment practices stretching across coerced and unfree labour, modern slavery, and exploitative employment practice. Ultimately, Scott shows how neoliberal political economy has reoriented workplaces and labour markets in a way that locates control with the employer and not the employee. With this control comes the ability to exploit, dispossess and harm workers in a variety of ways. In addressing similar underlying processes between exploitative conditions in the formal or legitimate labour market as well as harmful and coercive practices in illegal labour markets, this work demonstrates the underlying importance of political economy and highlights structural factors crucial in understanding the nature of work-based harm.

Finally, we must consider the formal labour market and its current conditions if we are to identify a wider continuum of illegal and exploitative practice. As labour markets continue to reflect neoliberal values of freedom, particularly freedom of movement and its accompanying flexibility (Standing 2011), the use of 'flexible' yet ultimately illegal and 'unfree' labour increasingly shapes legitimate labour markets (Gordon 2018). Flexibility and freedom in neoliberal terms masks an absence of stability and protection that manifests in both the conditions of employment (i.e. contractual status, benefits, protections) and working conditions (i.e. work process and workplace relations) (Lloyd 2018). This requires us to consider illegal labour and employment practice from the perspective of political economy.

According to Streeck (2016), the neoliberal agenda has seen the liberalisation of markets alongside a successful push to drive down wages in order to restore profitability. The value of wages has failed to keep pace with the return on capital investment over the last four decades (Piketty 2014; Mitchell and Fazi 2017). On the one hand, this generates growing inequality between workers and those with the means to invest (Piketty 2014) while on the other hand, the systematic control of wages allows employers to maximise surplus value as labour costs are minimised. As successive rounds of capitalist crises damage the demand for profitability and economic growth (Harvey 2010; Streeck 2016), the further diminution of labour rights and wages reflects a demand for profitability and growth. While states continue to attack labour rights and employment benefits, the use of illegal employment practices further bolsters the pursuit of profit. As noted above, costs drive the employment of illegal 
workers and the avoidance of tax and insurance responsibility compel some to under-report employee salaries.

In certain labour market sectors, the implementation of 'free' labour is not only routine but intrinsically tied to neoliberal values of individualism, competition and status. The 'cultural' or 'creative' industries of media, publishing, fashion, and the arts routinely employ unpaid interns ostensibly to provide skills and experience necessary to further the human capital of recent graduates who seek a foot on the career ladder (Shade and Jacobson 2015; Siebert and Wilson 2013; Perlin 2011). In a period of slow economic growth, supply outstrips demand and while interns absorb the master narrative of neoliberal competition and social mobility, organisations effectively dangle future careers in front of aspirational graduates yet simultaneously exploit them as free labour (Siebert and Wilson 2013). There is an inherent class bias and elitism attached to unpaid internships as parental support is necessary to sustain workers forced to give away labour for free in the hope of securing a career after 'paying their dues' (Shade and Jacobson 2015). In the creative industries, voluntary placements and internships provide free labour while creating value for the employer. Importantly, despite criticism and even court cases (Shade and Jacobson 2015), the use of interns is entirely legal.

Alongside the political economic driver to maximise surplus value and minimise employee power, the regulation of labour markets and workplaces is notoriously lax (Tombs and Whyte 2007). Skrivankova (2010: 4) notes, 'continual violation of standards can contribute to a more general undermining of the conditions of decent work and enable more extreme forms of violations to flourish, hence contributing to the existence of forced labour.' In other studies, the failure to pay the National Minimum Wage within certain sectors, including clothing and restaurant work, was not limited to illegal migrant workers (Ram et al 2002). Not only does the failure to enforce policy open the door to more problematic and socially harmful violations of human dignity, but this continuum stems from the same underlying function; the political-economic dynamic of late capitalism and its avowedly dogmatic and asocial pursuit of surplus value and reproduction. 
The systemic violence of capitalist social relations, particularly in its neoliberal phase, is missed if we focus on illegal labour as the 'unfree' work of illegal migrant workers. The rest of this paper will utilise data from two projects that investigated service economy work and will argue that illegal employment practices found within the service economy have similar roots to both illegal labour practices such as the employment of illegal migrant workers, as well as entirely legal practices such as the suppression of wages, the denial of workplace benefits and the absence of security, stability and protection.

\section{Methodology}

This paper combines data from two research projects that investigated employment in the service economy of North East England (see Lloyd 2012, 2013, 2017, 2018). The first project focused on a single research site, specifically a six-month covert ethnography of a call centre anonymised here and elsewhere as Call Direct. The author was employed as a Customer Service Representative (CSR) by Call Direct, an outsourced call centre providing facilities and staff to manage overflow calls for a broadband supplier named here as Internet Plus. Semistructured interviews with Call Direct employees and other call centre employees supplemented this data with 30 informal discussions accompanied by 15 recorded interviews.

The obvious methodological issue associated with the call centre project is the covert nature of the ethnographic research and its ethical implications. This is an important methodological consideration (Spicker 2011) but one that has been dealt with at length elsewhere (Calvey 2008; van Amstel 2013), including by the author (see Lloyd forthcoming). Essentially, covert research is neither a 'one-size fits all' nor an 'anything goes' approach to research (Calvey 2008: 908). Each organisation has techniques and practices that are hidden from outsiders (Fine and Shulman 2009) and for that reason a decision was taken to enter the field covertly in order to ensure the setting was encountered without limit or bias. Ethical clearance was attained by the host institution and corresponded to the ethical guidelines from both the British Society of Criminology and the British Sociological Association. Informed consent exists on a continuum across social research which, without exempting covert research from issues of consent, does problematise the notion that covert research is inherently bad for failing to ensure consent is given before inclusion in the project (Herrara 1999). Ethical questions relating to a moral responsibility for research participants and their well-being were 
taken in the field, a situated ethics that guided decision-making throughout the project rather than attempting to 'design out' potential risks at the planning stage (Calvey 2008).

The second research project aimed to build on the initial findings by widening the scope of inquiry to the wider service economy across an area of North East England. This project aimed to investigate whether or not the findings from the call centre project were unique to that setting or reflective of wider and more ubiquitous employment practices and working conditions. To this end, observational data were gathered from a wide variety of service economy occupations including retail, leisure services, food services, and the night-time economy. Additionally, over 20 interviews were conducted with service economy personnel, including call centre workers, retail staff, takeaway workers, delivery drivers and those employed in the night-time economy. Some respondents were interviewed more than once, across a two year period to discover changes and continuities across their careers whilst some respondents had also been involved in the first project.

All informants, in both projects, were characterised as either British White or British Asian, reflecting local demographics, split almost 50-50 across gender lines (reflecting the gender divide at Call Direct but not representative of the industry as a whole), aged predominantly between 18 and 30, and corresponding to what would traditionally have been called 'working class' but perhaps most appropriately fits 'precariat' or 'emerging service workers' in Savage et al's (2015) new class configuration.

The locale at the heart of these research projects has suffered deindustrialisation and the associated multitude of social problems in much the same way as any number of towns and cities across the UK, USA and Europe (see Winlow 2001; MacDonald and Marsh 2005; Linkon and Russo 2002; High 2003). In keeping with the literature on deindustrialisation, this town has also seen a significant shift in labour markets from industrial and manufacturing jobs to service and leisure industries (Shildrick et al 2012; Lloyd 2013; Winlow and Hall 2006). Along with this shift in labour market composition, an additional change has resulted in a shift from security and stability towards flexibility and insecurity (Lloyd 2018). The neoliberal agenda has been characterised by a downwards pressure on wages, the decimation of union power and the erosion of employee protection (Mitchell and Fazi 2017). Whilst the town at the heart 
of these projects is unique and has distinct features, it can also stand in for other towns and cities across Western neoliberal states that have seen the erosion of stable industrial work and the emergence of precarious and insecure service economy occupations. The insecurity and absent protections at the centre of the service economy create opportunities for employers to find ways of maximising surplus value at the expense of legal frameworks and employee rights. While not setting out to research illegal labour and employment practices, data uncovered in both projects presented an opportunity to explore this issue in more depth. The following sections will detail a number of illegal employment practices uncovered throughout these studies.

\section{Working for free}

During the call centre study, it became apparent that Call Direct would resort to ostensibly illegal practice in order to squeeze more work from employees wherever they could. Extracting maximum value from labour has been central to capitalist economics since its inception (Marx 1990 [1867]) while neoliberal values of efficiency and productivity (Lloyd forthcoming) underpin a specific approach to work routines, labour process and employment relations. This in itself is not new or revealing. However, Call Direct would also renege on contractually agreed-upon employment conditions, including holiday entitlement, in order to extract further value from already overworked and precarious employees. Formal labour markets, as noted above, are characterised by a degree of regulation and protection largely absent from informal and illicit economies yet statutory rights and obligations owed to employees were jettisoned in order to meet business need and satisfy customers. This moves legitimate employers into the realm of regulatory infraction or outright illegality.

This was true of both the working conditions within the call centre and the conditions of employment, including holiday entitlement. During the fieldwork in the call centre, a number of co-workers were denied their contractually obligated annual leave entitlements due to laborious and convoluted HR processes. The author was also denied three days annual leave. It appeared as though the leave request system and policy had been specifically designed to make it difficult for employees to access annual leave and left them in a position of working for free, should they fail to take their leave entitlement. One respondent, Phil, did not lose 
holidays or money whilst at Call Direct, but he did admit that the process of applying for holidays was problematic:

A - No, it's pretty bad. Only two people are allowed holidays at any one time where I am now...you just never got holidays.

$\mathrm{Q}-$ How many is there on your team now?

A - I think there's about fifteen.

Q - Fifteen people but there's only two allowed holidays at any one time?

A - Even though.... they've always had two off at any one time, even though they've just added three new people, they still only let two have holidays at once.

Call Direct used an intranet system whereby employees would submit holiday requests to the team leader who escalated it to an unseen HR department, located elsewhere in the building. CSRs only knew whether holidays were accepted or declined by checking the intranet and any queries directed to the team leader, not HR. The process became laborious when, as indicated above, only two members of a team were allowed off at any one time. With 15 people trying to submit requests, more often than not, they would be rejected and CSRs had to go through the process again. In the run up to the financial year-end in April, CSRs were told that any holidays not taken before $31^{\text {st }}$ March would be lost. Trying to repeatedly engage with a rigid process that allowed little leeway or support for CSRs left some unable to fulfil their holiday entitlement. Holidays could not be carried over and employees would not be paid extra for days they had been unable to take. Another respondent, Chrissie, was particularly critical of the holiday request system at Call Direct:

Q - What do you think of the system they've got for holidays?

A - It's pretty appalling actually.

$Q-\ln$ what respect?

A - In the respect that you... they request that you put holidays in, they'll send an email round saying that the people who haven't had holidays need to put them in for a certain month and then when you do it, you can put the whole month in and not get a day. They actually tell you to use the holidays and then you don't get them so there's no point really. 
Q - It is a first come, first served basis but do you think that it is too rigid in terms of being flexible towards people's needs? If something came up and you needed a day off next week then you wouldn't get it.

A - Yeah. There's no chance. I found myself that if you go the right way about getting a holiday then you won't get it, but if you then see the people you think might go that extra mile for you, they pick and choose who they want to do it for, you know what I mean? If they don't want to, there's no chance you're going to get it, if you really need a holiday for a week or two weeks, or even just a single day, they won't try their best for you. It's a case of taking the days off and you won't get paid, or just have unauthorised absences. They're just not flexible at all. They don't really understand personal issues, they should really do, you know, for long term agents that they've had working there for a long time and they know are reliable, they won't even be flexible with them.

By working at Call Direct for almost three years, Chrissie was in a position to make claims about management practices and behaviour, having been subject to them for so long. In her opinion, favouritism on the part of team leaders played a huge part in determining holiday entitlement. Although HR approved holiday requests, the requests came from a team leader therefore having a supportive team leader, especially in case of emergencies or when facing the prospect of losing holidays, was crucial. Without a committed team leader, CSRs had to fight for their entitlements before anything happened.

For the company, whether intended or accidental, it routinely gained extra value from its employees who were illegally denied their statutory rights. Employed on an annual salary, the denial of annual leave entitlement meant that the author worked three days for free, without any appropriate remuneration. Given the extent of this issue at Call Direct, it appeared to be standard operating procedure to demand adherence to a rigid internal bureaucracy that could routinely steal from employees. Reneging on contractual obligations such as this is only possible if organised labour is muted. The neoliberal project of taming union power and collective bargaining (Mitchell and Fazi 2017; Streeck 2016), particularly in the ascendant service sector, eradicates any potential for employee protest or resistance. As noted elsewhere, 'resistance' in this call centre amounted to individualised schemes to 'take 
back time' from an automated system rather than collectively challenge problematic and exploitative working conditions (Lloyd 2017). In the absence of any collective bargaining power, employers in the formal economy can cut corners and steal from employees without redress. Holiday entitlement is not only an employment right but a crucial factor in ensuring health and well-being (Dorling 2015). The physical and emotional impact of over-work is well documented (Wilkinson and Pickett 2009; Taylor et al 2003) therefore the denial of annual leave entitlement constitutes harmful and problematic working conditions. The following section focuses on the second research project which extends the identification of illicit practice beyond a single call centre employer.

\section{Off the books}

The imbalance between employers and employees is more pervasive than simply the dispossession of holiday entitlement or the absence of sick pay. Jason was 21 and worked for an independent clothing retailer. He regarded his employment as little more than an opportunity to pay for clothes, holidays and nights out as he was a full-time student who still lived with his parents. After four months of employment he could already point to several examples where he was dispossessed of workplace rights by an unscrupulous employer. At the time of the interview, the UK national minimum wage for workers aged 21 and over was $£ 6.70$ an hour. Jason earned $\mathrm{f6.50}$ an hour and usually worked three shifts a week,

$$
\begin{aligned}
& Q-\text { Minimum wage is } £ 6.70 \\
& A-\text { is it } £ 6.70 \text { now? } \\
& Q-\text { Yeah, so } f 6.50 \text {...they're paying you under the minimum wage. } \\
& A-I t \text { 's only twenty pence, man. }
\end{aligned}
$$

Guy Standing (2011) bifurcated the precariat into 'grinners' and 'groaners'. The groaners were those for whom precarious work was essential to their existence whereas 'grinners' represented retirees and students, for whom the flexibility of contemporary working configurations like zero-hour contracts and temporary working arrangements was beneficial. The flexibility at the heart of the service economy can be beneficial for students yet the transient nature of student labour creates an opportunity for employers to exploit young workers who are either ill-informed or simply uninterested in any rights that may apply to a 
temporary job. Jason and his employer epitomise this. Jason suggested that this job was a short-term measure; why worry about 20 pence? He liked his job, largely because it compared favourably with previous work experiences and it required very little of him ("it's a bit boring and it's repetitive but it's not actually hard graft"). Regular quiet shifts were a plus ('on a weekend it's busy but d'you know, on a weekday some days we've had one sale all day (laughs)") and he has fun with his co-workers. For Jason, this was enough to compensate for his exploitation. Furthermore, he had signed no contract, did not know whether he paid tax or deductions and seemed to think his manager paid him through direct bank transfer each week rather than BACS. From what Jason could or would reveal during his interview, he was employed off the books. This was further established when asked about his early experiences in this job,

A- no interview, no nowt [nothing]. He gave me a trial period, three days, but I didn't get paid for the three days and the trial period was like, they expected me to learn everything in three days and obviously it wasn't going to happen. I don't know what job you learn everything in three days...

$\mathrm{Q}$ - once you got through the trial and he took you on permanently did you get paid for those three days?

A - no, no. I got my lunch, I got a fiver a day (laughs)

$\mathrm{Q}$ - so he got three days free work out of you?

A - yeah

His employer extracted three days of free labour before offering Jason an hourly salary lower than the national minimum wage. Tellingly, this is not the only experience Jason has of this, having been on trial in a recycling factory which paid him $f 50$ per day for working 11 hour shifts. This demonstrates the ubiquity of illegal employment practices such as unpaid work trials across the formal economy. Undoubtedly, these practices exist within the informal economy but the fact that formal economy workplaces operate similar practices would indicate a driver that spans the continuum of legal and illegal work. The use of 'trial' periods to determine suitability serves unscrupulous employers and dangles permanent work in front of potential employees. That Jason laughed when he recounted both experiences of unpaid work trials is testimony to both the normalisation of precarious and nefarious employment 
practices within the service economy and his lack of identification with any form of low-paid service employment. It was all temporary. Trafficked migrants often labour for free in the hope and expectation that security and freedom awaits on the other side, often once debts are paid; here, under different circumstances, Jason also works for free while the carrot of security, in the form of permanent employment, dangles in front of him on the far side of his work trial. This was not the only example of exploitative illegal labour in this study.

Lee was 18 and sitting his A Levels. His part-time job in a takeaway was cash in hand and, as with Jason, below the national minimum wage. This corresponds with Ram et al (2002) who suggested that the failure to pay the minimum wage was not restricted to illegal migrant workers. Lee earned $£ 30$ a night for working seven hour shifts. He complained that his bosses were 'arseholes' who, after 18 months of employment, would still tell 'me I'm doing shit wrong'. He felt that his salary was "fucking shocking...but I can say a week in advance that I'm going to need next week off but I don't get paid" but despite these drawbacks it "keeps me in fags and drink...barely". As far as Lee was concerned, he needed this job but he had plans to finish college and then either attend university or look for apprenticeships. His current employment barely registered in his medium and long-term future. The transient nature of youth employment in an age of extended educational pathways provides employers with a supply of cheap labour who have no long-term commitment and more likely to put up with inconvenience and exploitative conditions. In these circumstances, with a pool of available labour largely unaware of, or unconcerned with, employment rights, some employers resort to illegal employment practices in order to keep costs low and, ultimately, profits high. The following section will consider these employment practices within a wider political economic context and the concept of 'accumulation by dispossession' (Harvey, 2010).

\section{Capitalist political economy and accumulation by dispossession}

The evidence above indicates that employers in the formal economy can and do willingly step outside regulatory frameworks and legal protections in ways that minimise costs and exploit workers. Illegal labour and employment practice, therefore, straddles both the formal and informal economy and perhaps can be said to exist on the continuum of exploitative labour practices identified by Scott (2017). This section draws on political economy and the work of 
David Harvey $(2005,2010)$ to establish the drivers and imperatives that generate these practices within the formal service economy as well as the informal or illicit economy.

The employment practices noted above break regulatory codes and legal frameworks but are all, at their core, acts of dispossession. Employees are dispossessed of rights, benefits, pay and security by employers compelled to participate within competitive markets (Lloyd 2018). Capitalism, at its most basic level, is a dynamic system of reproduction compelled to seek return on investment in order to ensure its own continuation (Harvey 2010). Marx's (1990 [1867]) interpretation of 'primitive accumulation' preceded capital accumulation and acted as the point of departure for capitalist investment. Marx departed from Adam Smith's 'previous accumulation' which presupposed a hardworking individual who accumulates enough capital to secure initial investment in the capitalist process and identified a historical process that divorced the producer from the means of production,

\begin{abstract}
"In actual history, it is a notorious fact that conquest, enslavement, robbery, murder, in short, force, play the greatest part. In the tender annals of political economy, the idyllic reigns from time immemorial. Right and 'labour' were from the beginning of time the sole means of enrichment, 'this year' of course always excepted. As a matter of fact, the methods of primitive accumulation are anything but idyllic." (Marx 1990 [1867]: 874).
\end{abstract}

So, in effect, primitive accumulation was a violent process of dispossession that extracted resource from those unable to protect themselves and furnished an emergent capitalist class with the means to begin the reproduction and accumulation process. David Harvey (2010) extends Marx's argument by asserting that primitive accumulation was not a one-off precursor that would green-light capitalist reproduction. Instead, Harvey suggests that the violence, exploitation, fraud and predation that characterise primitive accumulation continues today through a process of 'accumulation by dispossession',

\footnotetext{
“'But 'accumulation by dispossession' continues to play a role in assembling the initial money power. Both legal as well as illegal means - such as violence, criminality, fraud and predatory practices of the sort that have been uncovered in
} 
recent times in the subprime mortgage market, or even more significantly in the drug trade - are deployed. The legal means include privatisation of what were once considered common property resources (like water and education), the use of the power of eminent domain to seize assets, widespread practices of takeovers, mergers and the like that result in 'asset stripping', and reneging on, say, pension and health care obligations through bankruptcy proceedings." (Harvey 2010: 48-49).

'Accumulation by dispossession', then, provides the capital to reinvest in the cyclical process of capitalist reproduction. If capitalism's survival relies on the continual reinvestment of realised profit then ensuring sufficient surplus value exists, that a return on investment materialises, is crucial. On one level, the privatisation of Royal Mail by the British government in 2013 placed a public service in private hands for the purposes of profit-making. If we extend Harvey's (2010) concept of 'accumulation by dispossession' further, the continuum of legal and illegal employment practices discussed above offers a potential avenue for identification of labour market practice as driven by a political economic necessity, regardless of the legality of specific practices. The employment of illegal migrant labour is driven by the same culturally and economically prescribed motivation as the erosion of formal employment protections exemplified by the denial of annual leave entitlement or the use of unpaid work trials. All workers are dispossessed of something, whether it be the legal right to work, access to a minimum and living wage, benefits and protections, and, finally, a sense of security or stability.

If we side-step the question of legality and concentrate on political economy, we can identify a wider pattern that informs both formal and informal labour markets. Capitalism in its neoliberal phase is characterised by a political economic shift towards competition, market provision and private property (Harvey 2005; Mirowski 2013). Whilst the circulation of capital and the realisation of profit has been integral to capitalist political economy for centuries (Piketty 2014), under the neoliberal dispensation much of the regulatory framework that tempered the harsher effects of unbridled accumulation has been systematically eroded and undermined (Whitehead 2015; Streeck 2016; Mitchell and Fazi 2017). For some, neoliberalism represents a class project to 'restore' the capitalist class to its 'rightful place' 
(Harvey 2005; Badiou 2009), the systematic redistribution of resources and capital up the socio-economic and class hierarchy. The ideological belief in market freedom and the reconfiguration of government regulation in order to drive innovation, growth and profit serves the market at the expense of democracy (Streeck 2016), fairness and levels of inequality (Wilkinson and Pickett 2009).

Since the 2008 financial crisis, the servicing of capital and markets at the expense of the people and democracy represents a further retrenchment of capitalism and an attempt to overcome the crisis engendered through excess levels of public and private debt (Streeck 2016). This 'new spirit of capitalism' (Boltanski and Chiapello 2005), or what Streeck (2016) terms 'consolidated state', has sought to erode rights and benefits within formal labour markets. The erosion of employment protection, stability and rights has been widely noted throughout sociological literature (Madrick 2012; Heyes 2011; Lewchuk et al 2008; Wallace et al 2000) and represents not only the neoliberal shift towards efficiency, productivity and profitability (Lloyd forthcoming) but also reflects the necessity of realising profit in a depressed economy (Streeck 2016).

The ideological tenets of efficiency and productivity mask a fundamental retooling of most labour markets whereby employment protections and rights dwindle, working conditions deteriorate and the search for profit dominates. The 'coercive laws of competition' (Marx 1990 [1867]) compel businesses to absorb neoliberalism's key principles in order to stave off the threat of failure (Behling and Harvey 2015) as well as reach the heights of success in a 'winner takes all' culture (Cook and Frank 2010). As Tombs and Whyte (2015) suggest, networks of outsourcing and contracting engender a situation whereby those suppliers farthest from the top of the chain face diminished profit margins. In the supermarket horsemeat scandal of 2013, the supermarket chains sat at the top of a supply chain that was tainted at the lowest levels by unscrupulous contractors who cut corners to overcome tight margins (Tombs and Whyte 2015). Efficiency, productivity and profitability, in a competitive marketplace driven by the demand for profit and success can lead to illegal employment practices. 
The desire to realise profit in a low-growth economy is a fundamental problem. For some sectors, such as finance, profit can be realised through innovative technological development and algorithms that require little in the way of 'production' or labour. For many other sectors, particularly the formal and informal service sector, profit margins remain tight and surplus continues to be derived from consumer spending and low labour costs. For manufacturing and productive sectors, supply chain networks and contracts are offset by production and labour costs. Effectively, an opportunity to realise profit can be aided and abetted by the use of illegal labour or the illegal employment practices (Ram et al 2002). In the examples presented above, the use of 'off the books' staff allow employers to avoid tax and insurance obligations (Williams and Horodnic 2017); the use of 'work trials' provides free labour, as does the denial of annual leave entitlement. Each of these practices occurs within both the formal and informal economy and stem from the necessity to engage in competitive markets and a low-growth economy. While each set of practices and the legal status of employees may vary, the political economic driver underpinning these practices is constant.

The final point concerns the impact upon the employee. Various acts of dispossession serve to negatively affect employees in one way or another. Illegal migrants are overworked, underpaid and doubly precarious (Ahmad 2008a); formal service sector employees are also precarious, overworked, underpaid and beset by an absence of protection against unscrupulous employers (Lloyd 2018). A growing body of literature has begun to highlight the systemic harm perpetrated by capitalism and, in particular, neoliberal political economy (Hillyard and Tombs 2004; Pemberton 2016; Scott 2017). Pemberton (2016) notes that each variation on capitalist political economy has harmful consequences but states unequivocally that neoliberalism is harmful in the extreme. The systematic erosion of employment rights and protections in the name of efficiency, productivity, competition and profit (Scott 2017), the removal of social safety nets (Hillyard and Tombs 2017), and the demand to realise profit through increasingly problematic markets and avenues (Harvey 2010) leads to the exploitation of all workers, not only illegal migrants or those employed in the informal economy. Social harm theory also invites consideration of the harmful subjectivities engendered by neoliberal political economy and ideology (Hall and Winlow 2015; Lloyd 2018); those individuals and organisations willing to inflict harm on others in order to succeed in a competitive market economy and a culture of competitive individualism (see also Smith and 
Raymen 2016). Employers appear willing to exploit and undermine their employees in order to profit and the regulatory overhaul enacted under conditions of neoliberalism provides the space and freedom to do this with seeming impunity.

\section{Conclusion}

This paper started from the position that illegal labour was often bound up with discussion of human trafficking, migrant smuggling and modern slavery. The intention has not been to dismiss or minimise the truth of this claim nor to state a moral equivalence between modern slavery and illegal employment practices in the formal economy. However, in raising the level of analysis above the labour market, workplace, the employee or the criminal gang to the level of political economy, this paper has argued that a set of political economic drivers create a motivation and rationale to systematically seek profit and capital wherever possible, at the expense of employee rights, well-being and safety. The motivation to employ an illegal migrant in a restaurant or clothing factory (Ram et al 2002) comes from the same place as the motivation to deny call centre workers annual leave entitlement or employ students on unpaid work trials. The mechanisms for dispossessing employees of rights, pay and protection differ from one example to the next but the driving force behind these practices is the capitalist mode of production and its current manifestation in a neoliberal ideology of competition and profitability.

The evidence presented here shows that illegal employment practices frequently occur within the formal economy. Two small-scale projects in the North East of England generated a surprisingly significant amount of data on various illegal and unethical practices. This paper presents a first foray into the issue of illegal labour. The challenge will be to extend this further and explore illegal employment practice more widely. The literature on employment of illegal migrant labour is often tied to criminological discussion of migrant smuggling, forced exploitation, human trafficking and modern slavery (Boswell and Straubhaar 2004). This alone presents an opportunity for organised crime scholars to contemplate the role of work and labour in the practices of organised crime networks operating under conditions of neoliberal political economy. However, in contemplating labour market exploitation along a wider continuum of social harm (Scott 2017) and identifying the political economic driver for both legal and illegal practice in a variety of working environments, it could be argued that 
the true 'organised crime' taking place here is the violence of neoliberal political economy and its deliberate erosion and undermining of employment rights and protections, eradicated in the name of profitability. 


\section{References}

Ahmad AN (2008a) Dead man working: Time and space in London's (illegal) migrant economy, Work, Employment \& Society, 22(2) 301-318.

Ahmad AN (2008b) The labour market consequences of human smuggling: 'illegal' employment in London's migrant economy, Journal of Ethnic and Migration Studies, 34(6) 853-874.

Antonopoulos GA and Winterdyk J (2006) "The smuggling of migrants in Greece: An examination of its social organisation", European Journal of Criminology. 3(4) 439-461.

Antonopoulos GA and Papanicolaou G (2018) Organized Crime: A Very Short Introduction, Oxford: University Press.

Badiou A (2009) The Century, Cambridge: Polity Press.

Bales K (2012) Disposable Bodies: New Slavery in the Global Economy, Oakland: University of California Press.

Behling F and Harvey M (2015) "The evolution of false self-employment in the British construction industry: A neo-Polanyian account of labour market formation", Work, Employment and Society, 29(6) 969-988.

Boltanski L and Chiapello E (2005) The New Spirit of Capitalism, London: Verso.

Boswell C and Straubhaar T (2004) The illegal employment of foreign workers: An overview, Intereconomics, 39(1) 4-7.

Calvey D (2008) 'The art and politics of covert research: Doing 'situated ethics' in the field' Sociology, 42(5) 905-918.

Campana P and Varese F (2015) "Exploitation in human trafficking and smuggling", European Journal on Criminal Policy and Research, 22(1) 89-105.

Cook PJ and Frank RH (2010) The Winner Take-All Society, New York: Virgin Books.

Dorling D (2015) Injustice: Why Social Inequality Still Persists, Revised Edition, Bristol: Policy Press.

Entorf $\mathrm{H}$ and Moebert J (2004) The demand for illegal migration and market outcomes, Intereconomics, 39(1) 7-10.

Fine GA and Shuman D (2009) 'Lies from the field: Ethical issues in organizational ethnography' in Ybema S, Yanow D, Wels H and Kamsteeg FH (Eds) Organizational Ethnography: Studying the Complexity of Everyday Life, London: Sage. 
Gordon T (2018) Capitalism, neoliberalism and unfree labour, Critical Sociology, online first at https://doi.org/10.1177/0896920518763936

Hall A and Antonopoulos GA (2016) Fake Meds Online: The Internet and the Transnational Market in Illicit Pharmaceuticals, Basingstoke: Palgrave Pivot.

Hall S and Winlow S (2015) Revitalizing Criminological Theory: Towards a New Ultra-Realism, London: Routledge.

Harvey D (2005) A Brief History of Neoliberalism, Oxford: University Press.

Harvey D (2010) The Enigma of Capital: And the Crises of Capitalism, London: Profile.

Hatton E (2018) 'Either you do it or you're going to the box': Coerced labour in Contemporary America', Critical Sociology, online first at https://doi.org/10.1177/0896920518763929

Herrara CD (1999) 'Two arguments for 'covert methods' in social research' The British Journal of Sociology, 50(2) 331-343.

Heyes J (2011) 'Flexicurity, employment protection and the jobs crisis', Work, Employment and Society, 25(4), 642-657.

High S (2003) Industrial Sunset: The Making of North America's Rust Belt, 1969-1984, London: University of Toronto Press.

Hillyard P and Tombs S (2004) 'Beyond Criminology?' in Hillyard P, Pantazis C, Tombs S and Gordon D (Eds) Beyond Criminology: Taking Harm Seriously, London: Pluto Press.

Hillyard P and Tombs S (2017) 'Social harm and zemiology' in Liebling A, Maruna S and McAra L (Eds.) The Oxford Handbook of Criminology, (6 $6^{\text {th }}$ Ed.) Oxford: University Press.

Large J (2018) 'Spot the fashion victim(s): The importance of rethinking harm within the context of fashion counterfeiting' in Boukli P and Kotzé J (Eds) Zemiology: Reconnecting Crime and Social Harm, Basingstoke: Palgrave Macmillan.

Lewchuk W, Clarke M and Wolff A (2008) 'Working without commitments: Precarious employment and health', Work, Employment and Society, 22(3), 387-406.

Linkon SL and Russo J (2002) Steeltown USA: Work and memory in Youngstown. Kansas: University Press.

Lloyd A (2012) "Working to live, not living to work: Work, leisure and youth identity among call centre workers in North East England", Current Sociology, 60(5) 619-635.

Lloyd A (2013) Labour Markets and Identity on the Post-Industrial Assembly Line, Farnham: Ashgate. 
Lloyd A (2017) "Ideology at Work: Reconsidering ideology, the labour process and workplace resistance", International Journal of Sociology and Social Policy, 37(5/6) 266-279.

Lloyd A (2018). The Harms of Work: An Ultra-Realist Account of the Service Economy, Bristol: Policy Press.

Lloyd A (forthcoming) 'Efficiency, productivity and targets: The gap between rhetoric and reality in the call centre', Critical Sociology

MacDonald R and Marsh J (2005) Disconnected Youth? Growing Up in Britain's Poor Neighbourhoods, Basingstoke: Palgrave.

Madrick J (2012) 'The deliberate low-wage, high-insecurity economic model', Work and Occupations, 39(4), 321-330.

Marx K (1990 [1867]) Capital. Vol. 1, Oxford: University Press.

Mirowski P (2013) Never Let a Serious Crisis Go To Waste, London: Verso.

Mitchell W and Fazi T (2017) Reclaiming the State, London: Pluto Press.

Nikolic-Ristanovic V (2004) Illegal markets, human trade and transnational organised crime, in van Duyne PC et al (Eds.) Threats and Phantoms of Organised Crime, Corruption and Terrorism: Rhetoric and Critical Perspectives, Wolf Publishing Limited.

Papanicolaou G (2008) “The sex industry, human trafficking and the global prohibition regime: A cautionary tale from Greece", Trends in Organised Crime. 11. 379-409.

Pemberton S (2016) Harmful Societies: Understanding Social Harm, Bristol: Policy Press.

Perlin R (2011) Intern Nation, London: Verso.

Piketty T (2014) Capital in the Twenty-First Century, London: Belknap.

Ram M, Edwards P and Jones T (2002) Employers and Illegal Migrant Workers in the Clothing and Restaurant Sectors, London: DTI Central Unit Research.

Savage M et al. (2015) Social Class in the $21^{\text {st }}$ Century. UK: Pelican.

Scott S (2017) Labour Exploitation and Work-Based Harm, Bristol: Policy Press.

Shade LR and Jacobson J (2015) "Hungry for the job: Gender, unpaid internships, and the creative industries", The Sociological Review, 63(S1) 188-205.

Shen A, Antonopoulos GA, and Papanicolaou G (2013) “China's stolen children: Internal child trafficking in the People's Republic of China", Trends in Organised Crime. 16. 31-48.

Shildrick T, MacDonald R, Webster C and Garthwaite K (2012) Poverty and Insecurity, Bristol: Policy Press. 
Siebert S and Wilson F (2013) "All work and no pay: Consequences of unpaid work experience in the creative industries", Work, Employment and Society, 27(4) 711-721.

Skrivankova K (2010) Between Decent Work and Forced Labour: Examining the Continuum of Exploitation, Joseph Rowntree Foundation Programme Paper.

Smith O and Raymen T (2016) 'Deviant leisure: A criminological perspective', Theoretical Criminology, Online first t at http://journals.sagepub.com/doi/full/10.1177/1362480616660188

Spicker P (2011) “Ethical covert research", Sociology. 45(1) 118-133.

Standing G (2011) The Precariat: The New Dangerous Class, London: Bloomsbury.

Streeck W (2016) How Will Capitalism End? London: Verso.

Taylor P et al (2003) "A unique working environment': Health, sickness and absence management in UK call centres' Work, Employment and Society, 17(3) 435-458.

Tombs S and Whyte D (2007) Safety Crimes, Cullompton: Willan.

Tombs S and Whyte D (2015) The Corporate Criminal, London: Routledge.

UNODC (2016) Global Report on Trafficking in Persons 2016, United Nations Publication.

Van Amstel H (2013) "The ethics and arguments surrounding covert research", Social Cosmos. 4(1) 21-26.

Venturini A (2004) Do illegal migrants compete with national workers? Intereconomics, 39(1) 11-13.

Wacquant L (2009) Punishing the Poor: The Neoliberal Government of Social Insecurity, Duke: University Press.

Wallace CM, Eagleson G and Waldersee R (2000) 'The sacrificial HR strategy in call centers', International Journal of Service Industry Management, 11(2), 174-184.

Webb JW et al (2009) You say illegal, I say legitimate: Entrepreneurship in the informal economy, Academy of Management Review, 34(3) 492-510.

Whitehead P (2015) Reconceptualising the Moral Economy of Criminal Justice, Basingstoke: Palgrave Pivot.

Wilkinson R and Pickett K (2009) The Spirit Level: Why Equality is Better for Everyone, London: Penguin.

Williams CC and Horodnic IA (2017) Evaluating the illegal employer practice of underreporting employees' salaries, British Journal of Industrial Relations, 55(1) 83-111.

Winlow S (2001) Badfellas: Crime, Tradition and New Masculinities, Oxford: Berg. 
Winlow S and Hall S (2006) Violent Night: Urban Leisure and Contemporary Culture. Oxford: Berg.

Winlow S, Hall S and Treadwell J (2017) The Rise of the Right: English Nationalism and the Transformation of Working-Class Politics, Bristol: Policy Press. 